\title{
Discussion on Pictorial Photography and Pure Photography in the Development of Photographic Art
}

\author{
Xue Niu \\ Wuhan Technology and Business University \\ Wuhan, China
}

\begin{abstract}
During the developing process of photography, technology and art have mutual collision and fusion, so that photography has produced many different genres, among which pictorial photography and pure photography are of early emergence. They have their own aesthetic rules and laws. The collision and connection between pictorial photography and pure photography promoted the emergence and development of other genres. If we clarify the relationship between painting and photography, as well as the relationship between pictorial photography and pure photography, we can grasp the development of early photographic art.
\end{abstract}

Keywords-photographic art; pictorial photography; pure photography

\section{INTRODUCTION}

Photography originated in the nineteenth century in France. On August 19, 1839, when Frenchmen identified Daguerre's daguerreotype as the earliest photographic technique, and made it public by Academy of France and the Art Academy of France, which showed that the development of photography benefited from two supports; one was the engineering technology of natural science, and the other one was the plastic arts of humanities. The two supports are not fully synchronized, or not even on the same track.

As an independent art, photography, with its own unique value, is playing an indispensable role in today's "age of image", and is deeply penetrating into all fields of human society; it has intervened into our life with an unprecedented scale and become one of the basic skills necessary to modern humans. As a scientific technique, photography, with a very high technical content and rich artistic elements, not only asks photographers to master related basic knowledge, skills and techniques of photography, but also has high requirements of photographer's level of knowledge, aesthetic skills and artistic experience. During the developing process of photography, technology and art had mutual collision and fusion, so that photography generated lots of genres.

\section{PICTORIAL PHOTOGRAPHY}

During the first decades of photography's birth, photographers' primary focus was on the research and optimization of photographic equipment and photographic chemistry. Few people took considerations in the artistic styles

A Teaching Reform Project: The Study on Practical Teaching of Business Photography Courses in Colleges and Universities, Project Number: 2014 Y04. of photography. With the gradual maturity of photography, people began to pay attention to techniques and aesthetics. The complicated operation process, the heavy equipment and the influence of painting art on photography brought photography onto the road to imitate painting, so pictorial photography naturally appeared, as the first genre of photography.

Pictorial photography was a genre of photographic art popular from the mid-19th century to the early 20th century, which originated in about 1850 in the United Kingdom. For photography was just invented, many painters and artists with deep aesthetic cultivation were obsessed with the wonderful reappearance power of photography. They turned from painting to photography, and they pursued the painting effect of the photographic works or "the beauty of poetic paintings". In 1869, Henry Peach Robinson (1830-1901) published his book-Pictorial Effect in Photography, which laid the theoretical basis for pictorial photography. He noted," photographers must have rich emotions and a deep understanding of the art, so that they can become good artists. Beyond doubt, the continuous improvement and inventions of photography provide artists a world where they can free play, but the technical progress is not necessarily equal to the progress of art. No matter how sophisticated and complete the skill becomes itself, for the pursuit of photographic art, it will still lead us to a higher goal."

Both as the visual arts, painting and photography have an inseparable intimate relation between each other, which was obviously reflected in the photography works in the early years in particular. The aesthetic criterion of pictorial photography is artistic quality of photography works, with the premise of painting. Early pictorial photography was a popular fashion with a tendency to classical aesthetics. The style of early pictorial photography reflected the attachment of the early artistic photography on painting. On the other hand, it also showed the spirit of photographers pursuing the photographic art. It is the persistent pursuit that laid the foundation for the artistic position and development that photography obtained.

The establishment of associations like The Linked Ring, Hamburg Pictorial Photography Exhibition, Paris Photography Club, London Photography Salon and related photography activities, made pictorial photography reached its peak during late 19th century and early 20th century. Around the 1920s, with the rise of direct photography and the impact of photosecession in later years, pictorial photography gradually declined. 


\section{A. High Art Photography}

In the 1850s, high art photography rose up in the United Kingdom, and during 50's to 80's, it was the heyday of the development of high art photography. High art photography was deeply influenced by the "pre-Raphaelite" photography; the themes high art photography present are mostly religious, and the resources of the themes are basically from the Bible, poetries, and history, etc. High art photography is to use the rules and principles of painting and the techniques of photography, to obtain the effect of painting. During photographing, photographers pursue the classical painting effect on purpose; in order to achieve some kind of effect, directors' arranging skills can be chosen. Photographers designed the sketches first, selected the models and props, carefully organized the scene, and finally finished the work through the processing in the darkroom. High art photography is represented by Oscar Gustave Reilander (1813-1875), Henry Peach Robinson (1830-1901), Julia Margaret Cameron (Julia Margaret Cameron, 1815-1879), et al.

\section{B. Impressionistic Photography}

Impressionistic photography was produced under the influence of Impressionist paintings, and got on the stage of photographic art at the end of the 19th century and the beginning of the 20th century. Impressionistic photography pursues a hazy and vague beauty. Many photographers began to use a variety of soft focus skills to shoot photos, and use gauze photo papers and gum bichromate process, or even directly use rubbers and brushes on photos to produce a rough texture effect, which are all to achieve the effect of hazy beauty. Representatives of impression photography are George Davison (1856-1930), John Dudley Johnston (1868-1955), Robert Demachy (1859-1936), Heinrich Kuehn (1866-1944), and Emile Joachim Constant Puyo (1857-1933), et al.

\section{Naturalistic Photography}

With the decay of high art photography, naturalistic photography, as a genre of pictorial photography in a realistic style, began to thrive in the 1880s. Naturalistic photography considers pictorial photography as the artificial salon photography dedicated to exhibitions, incompatible with the vivid natural reality. Naturalist photographers advocated the return to the nature to pursue creative inspirations; they also called on photographers to re-attach importance to personal experience, and shoot works, in real environment, with realistic skills, to present the real original appearance of the subject. In 1889, Peter Henry Emerson (1856-1936) wrote a book called Naturalistic Photography for Students of Art, which is considered as the declaration of naturalistic photography. The emergence of naturalistic photography changed the atmosphere of focusing on dignitaries at that time. Photographers started to focus on the nature and the daily life of ordinary people in the society. Therefore, naturalistic photography usually takes natural scenery and social life as its themes. Representatives of naturalist photography are Peter Henry Emerson (1856-1936), Frank Meadow Sutcliffe (18531941), Lidell Sawyer (1856-1895), et al.

\section{PURE PHOTOGRAPHY}

Pure Photography was born in the early 20th century, on the basis against pictorial photography. The reason why it is called Pure Photography is that this genre advocates photographic art should obtain the unique artistic and aesthetic effect pf photography by the purely photographic means. Pictorial photography allows acting, post-clip, and the use of various techniques and methods to control the scene; pure photography points that photography should show its own characteristics, and it is opposed to the imitation based on realistic painting, and artificial post-processing and modification on photos; it advocates rely solely on the use of photographic equipment like cameras, lenses and photosensitive materials to obtain special aesthetic images. It pursues the focus as clear as possible, the depth of field as wide as possible, and the size of the negative as large as possible, so that the works, on the aspect of photographic art, achieve premium "photographic quality"; it also accurately, directly, subtly and naturally performs the light, Lines, tone, color, texture, and other aspects of the subject.

The French, Eugene Atget (1857-1927) and the German, Albert Renger Patzch (1897-1966) are the two most representative photographers of early pure photography. When Atget was alive, he was a nameless photographer who sold his photographs to make ends meet. From 1897, Atget, with simple camera and simple techniques, started shooting the streets of Paris. Meanwhile, Europe was at the stage when pictorial photography dominated the world, and almost all of the photographers were trying everything to get their works close to pictorial photography. However, Atget didn't follow the mainstream, and began his lonely photography life ever since. Agate took more than 10,000 negatives in more than 30 years, which, until the 1930s, were found by the assistant of American photographer Manley. Many of Atget's photos and negatives were bought by the assistant through fundraising, so that these images had made a huge impact on the whole world. Agate's photos recorded the subtle perceptual knowledge directly, which might be the earliest presentation method of pure photography. Patzch's photographing skills are fresh and straight forward, and in his published photograph album -- The World Is Beautiful, most of the works are of clear imaging and rich tones, including many photos with features of pure photography.

Patzch's works and presentation skills were quickly spread to the United States across the Atlantic, which made some photographers, who had already been very successful in pictorial photography, joined the camp of pure photography in succession, such as Alfred Stieglitz (1864-1946), Edward Steichen (1879-1973), Paul Strand (1890-1976) and others. During the early period of the American pure photography movement, the most influential figure was Paul Strand, who began to photograph a group of pictures that were particularly sharp and focused since 1915. Strand's works were full of black and white tones, which can stimulate the beauty of details.

The emergence of pure photography was the first revolution in the history of photography, but also a very meaningful revolution so far in order to establish photography 
as an independent art category distinguished from other art forms. It marked that photography started to get out of the form of painting, and to truly return to its essence, and it also marked the further awakening of the concept of photographic art itself. It completely shook the position of pictorial photography in the world of film status, and promoted the photographic art and technology development.

\section{A. Photo-secession Movement}

Founded in 1902, the photo-secession was an American photographic organization active in the early 20th century. Because at that time the initiators and the main members of it were almost explorers of impressionistic photography, so photo-secession is basically a branch of The Linked Ring in the United States. During the first five years of its establishment, on the one hand, the members of the photosecession continued the aesthetic concept of The Linked Ring; and on the other hand, they tried to admire and promote various avant-garde art trends and photography experiments. The "291" art gallery, hosted by Stiglitz, was one of the most influential cultural centers in the American Continent, with many multinational photography competitions and various painting exhibitions held here. From 1907, photographers in the photo-secession, who advocated direct, immediate, and instant photography should be better than pictorial photography, and who used impressionistic photography to deliberately reduce the impact on the sharpness of photographs, are gradually taking the superior position. Stiglitz, Steichen and Strand et al. became the advocates of direct photography. As impressionistic photography and direct photography are of different aesthetic ideas, or even in opposition to each other, leading to a series of internal contradictions in The Linked Ring. In 1908, photo-secession and The Linked Ring broke up with each other, and The Linked Ring, with hard hits, officially disintegrated in 1910. This marked the ultimate separation of photography from painting. The "classical age" when Photography was attached to painting finally come to an end. The base camp of photography moved from Europe to the United States.

Photo-secession movement successful transformed pictorial photography into direct photography, playing a role of connecting the past and the future for the transformation from pictorial photography into pure photography. Representatives of Photo-secession are Alfred Stieglitz (1864-1946), Edward Steichen (1879-1973), Paul Strand (1890-1976), Joseph Turner Keiley (1869-1914), Gretrude Kasebier (1852-1934), Clarence Hudson White (1871-1925), Alvin Langdon Coburn (18821966), Anne Brigman (1868-1950), and Frank Eugene (18651936), et al.

\section{B. New Objectivism Photography}

New objectivism photography, also called neo-materialist photography, a branch developed by pure photography, appeared in the 1920s. New objectivism points out that photography has its own characteristics, to objectively and accurately reproduce things, and to explain the nature of them, which is the quality that can't be replaced by that of any other art.
New objectivism photographers are focusing on the nature, industries, and the ordinary things in contemporary society. They stress that photography should pursue beauty through its own characteristics, focusing on shooting photographs of rich details in reality, and also emphasizing the light in the presentation of a work. On the means of presentation, it emphasizes through observation and discovery, making a real and meticulous depiction of the objective world, by intuitive and realistic approach. It abandons the observation of the big scene, but turns to the concern on the parts and details; it amplifies the parts of a subject with techniques like shortdistance and close-up shooting, with accurately description of a certain part of the subject, to separate the part out of the whole subject and to produce a special visual effect on the form and texture. Representatives of new objectivism photography are Albert Renger Patzch (1897-1966) and Karl Blossfeldt (1865-1932).

Karl Blossfeldt's photography is best known for photos of plants and ferns. These photos faithfully captured the details of the plants in the nature by close-up shots; those parts of the plants were details never noticed by others. His series of plants are almost all abstract, and some even become abstract graphics, these photographs seem to have blurred the boundaries of records and aesthetics. Carl Bloomsfield and the work of new objectivist photographer far-reaching impact, the United States photographer Edward Henry Weston (Edward Henry Weston, 1886-1958) some of the close-up works on the new objectivism style of photography.

\section{Group F/64}

Group F/64 is an organization that really pushed pure photography to a peak. This is a group set up in 1932, by a group of photographers living in California, the west coast of the United States. The main members are Edward Henry Weston (1886-1958), Ansel Adams (1902-1984), Imogen Cunningham (1883-1976), Willard Van Dyke (1906-1986), etc. Group F/64 had no person in charge, did not hold any meeting, and do not pay dues, so it was disbanded in 1935. It emphasizes the "pure" and "direct" style of presentation, requiring direct shooting of original things; the pictures should be all clear, all levels of the tone should be subtle and rich; it promotes the use of large space camera during shooting, and if necessary, the aperture should be reduced to a minimum of F64, to maintain the purity of photography by controlling the exposure, development and printing technology and relying on pure photography technique. Group F/64 pushed the photographic works with the style of pure photography to a new level, and took the aesthetic ideas of pure photography to the extreme.

\section{CONCLUSION}

Pictorial photography and pure photography are the two major genres during the early development of photographic art. They have a lot of connections with each other. For example, photography separatist Stiglitz, Steichen and Strand in the photo-secession movement are recognized as the representatives of pictorial photography in the United States. After the photo-secession movement, they have to join the camp of direct photography camp in succession, shooting a lot 
of classic works of pictorial photography. Strand especially took explorations of many aspects of different styles such as pure, pictorial, documentary, and abstract styles.

The mutual collision and connection between the two major genres also promoted the emergence and development of other genres. After 1920s, photography entered into a mature period, and photography and business were increasingly integrated together. The emergence of a variety of social trends and artistic styles made the style of photography constantly change; in addition to pictorial and pure photography, a number of photography genres appeared such as documentary, abstract, surrealism, Dadaism, neo-realism, commercial imagery, and absurd. However, regardless of the changes in the thinking of photography or the difference of the presentation styles, these new genres all have been influenced by pictorial photography and pure photography. Clarify the relationship between photography and painting, as well as the relationship between pictorial photography and pure photography, and we can grasp the development vein of early photographic art.

\section{REFERENCES}

[1] Zhang Xiong, Wang Lin, etc.2007. "The Basis of Modern Photography" [M]. Hunan People's Publishing House.

[2] Yi Ke.2008. "The History of Photography" [M]. Chongqing Publishing House. 